\title{
Improvement in gait performance in oldest-old with chronic pain, after acupuncture intervention
}

\section{Melhora na performance da marcha no longevo com dor crônica, após a intervenção de acupuntura}

\author{
Carina Zuppa', Fabrício Oliveira Cardoso², Eleia de Macedo³, Ângelo José Gonçalves Bós ${ }^{4}$ \\ PhD student, in Biomedical Gerontology Program, Pontifical Catholic University of Rio Grande do Sul. Porto Alegre, RS, Brazil. \\ <carinazuppa@hotmail.com> \\ ${ }^{2}$ Master student, in the Biomedical Gerontology Program of the Pontifical Catholic University of Rio Grande do Sul. Porto Alegre, RS, Brazil. \\ <fabriciocardoso291@gmail.com> \\ ${ }^{3}$ PhD student in the Biomedical Gerontology Program of the Pontifical Catholic University of Rio Grande do Sul. Porto Alegre, RS, Brazil. \\ <eleiamacedo@yahoo.com.br> \\ ${ }^{4}$ Adjunct Professor of the Postgraduate Biomedical Gerontology Program, Pontifical Catholic University of Rio Grande do Sul. Porto Alegre, RS, Brazil. \\ <angelo.bos@pucrs.br>
}

\section{ARTICLE INFO}

\section{Article history}

Received: 2017/11/10

Accepted: 2018/04/18

\section{Correspondent Author}

Carina Zuppa

Av. Ipiranga, 6681 - Prédio 81

90619-900 Porto Alegre, RS, Brazil

<carinazuppa@hotmail.com>

(C) 2018 All rights reserved

\section{Editors}

Alfredo Cataldo Neto

Paula Engroff

\begin{abstract}
AIMS: This study aimed to observe the possible benefits of acupuncture in chronic pain and gait performance of oldest-old, people aged 80 and older. METHOD: The study population consisted of oldest-old with chronic pain. For the initial assessment of pain was used a questionnaire containing a figure with anatomical regions and intensity of pain referred by the participant. The evaluation of the gait performance we used the Zeno walkway that has electronic sensors pressure and evaluates various gait parameters. After 10 acupuncture sessions, pain intensity and gait performance were reevaluated. The sessions had a frequency of twice a week and treatment was performed individually for several protocols points according to the illness or pain reported by each patient. RESULTS: Twenty-three oldest-old were initially enrolled, 16 completed the ten sessions of acupuncture and proposed assessments. In the final evaluation, the intensity of pain decreased in 12 of the 13 sites initially referred. In gait parameters, we achieved significant improvement in step and stride length, increased gait speed and cadence. CONCLUSIONS: Demonstrated with this study that the acupuncture treatment was effective in reducing chronic pain and improvement in gait performance of the oldest-old.
\end{abstract}

KEYWORDS: acupuncture; chronic pain; gait; oldest; primary health care.

\section{RESUMO}

OBJETIVOS: Este estudo teve como objetivo observar os possíveis benefícios da acupuntura na dor crônica e desempenho da marcha dos idosos, com 80 anos ou mais. MÉTODO: A população estudada consistiu em idosos com dor crônica. Para a avaliação inicial da dor foi utilizado um questionário contendo uma figura com regiões anatômicas e intensidade de dor referida pelo participante. A avaliação do desempenho da marcha usou o tapete Zeno que possui sensores eletrônicos de pressão e avalia vários parâmetros de marcha. Após 10 sessões de acupuntura, a intensidade da dor e o desempenho da marcha foram reavaliados. As sessões tiveram uma frequência de duas vezes por semana e o tratamento foi realizado individualmente para vários pontos de protocolo de acordo com a doença ou dor relatada por cada paciente. RESULTADOS: Vinte e três longevos iniciaram o tratamento, 16 completaram as dez sessões de acupuntura e avaliações propostas. Na avaliação final, a intensidade da dor diminuiu em 12 das 13 regiões inicialmente referidas. Nos parâmetros da marcha, conseguimos uma melhoria significativa no comprimento do passo, aumento da velocidade da marcha e cadência. CONCLUSÕES: o estudo demonstou que o tratamento de acupuntura foi efetivo na redução da dor crônica e melhora no desempenho da marcha dos idosos longevos.

DESCRITORES: acupuntura; dor crônica; marcha; idoso de 80 anos ou mais; atenção primária à saúde. 


\section{INTRODUCTION}

The demographic and epidemiological transition in progress in recent decades in the Brazil are followed by the growth of the elderly population. ${ }^{1}$ Aging is a natural and progressive process in humans, accompanied by physical, functional and psychological changes. Older age can be associated with health problems, loss of quality of life, depression, weakness, chronic pain, difficulty walking and balance. ${ }^{2-4}$ In this population context was created, at the Institute of Geriatrics at the Pontifical Catholic University of Rio Grande do Sul - Brazil, the Assistance to the Oldest-old (AMPAL) in order to better meet the needs of care and clinical care of long-lived individuals. ${ }^{5-6}$

The firsts results in AMPAL observed a significant frequency oldest-old with frailty syndrome (FS) and a significant proportion of them with chronic pain, changes in the balance and gait difficulties whose association is described as existing in relation to FS, this results in higher costs to health..$^{7-8}$ Recently published guidelines, such as the National Policy on Integrative and Complementary Practices (PNPIC), encourage the practice of acupuncture in primary health care (PHC) in Brazil. This Brazilian policy contributes to implement experiences in the sector of traditional Chinese medicine and complementary therapies in PHC. $5,9,10$

The practice of acupuncture is health interventions that have a comprehensive approach and dynamic to the health-disease in humans and can be used alone or integrated with other therapeutic resources. Originating from Traditional Chinese Medicine (TCM), acupuncture comprises a set of procedures allow precise the stimulation of anatomical locations defined by inserting needles for promotion, maintenance and restoration of health and prevention of injuries and diseases. ${ }^{9,11}$

Changes in gait are very prevalent in the elderly and can lead to serious consequences, such as falls, fractures and loss of independence. ${ }^{12}$ Using Acupuncture it may be possible provide pain relief, good results in postural control and can be used to treat the symptoms of the frailty syndrome and reduce the risk of falls, these problems that affect the very oldest-old people. ${ }^{12}$

\section{METHOD}

This study was approved by the Committee of Ethics in Research of the Pontifical Catholic University of Rio Grande do Sul (CAAE 30289014.9.0000.5336), in agreement with the World Medical Association for experiences in human beings and follows the ethical principles of Resolution 466 of the National Council of Brazilian Health. The elderly participants of the research were given all the information about all stages of the research and gave their informed consent.

The study sample consists of 23 oldest old (aged over 80 years), men and women living in Porto Alegre - Brazil, recruited by convenience and availability. Initially we conducted a pilot test with assessment instruments and acupuncture; procedures were performed in January 2014 at the University Extension Center Vila Fatima (CEUVF) of the Pontifical Catholic University of Rio Grande do Sul (PUCRS). The CEUVF is a center that provides services to the primary care level. The inclusion criteria: to participate in the acupuncture sessions offered by the project. The exclusion criteria were to have skin lesions located at the sites of the acupuncture points.

Data collection and acupuncture intervention procedures happened between March 2014 to April 2015, in the Laboratory for Assessment and Research in Physical Activity (LAPAFI) of the School of Physical Education and Sport Sciences (FEFID) of PUCRS. We excluded the participants who had communication difficulties and those who are at an imminent risk of fall and those who the examiner judged as dangerous to the integrity of the participant during the walking test.

For the initial assessment was used an instrument based on the Elderly Multidisciplinary Evaluation of the Ministry of Health, ${ }^{13}$ adding questions about the clinical conditions such as chronic pain, difficulty in walking. The same instrument was used in the revaluation of oldest-old after the intervention and control. ${ }^{14}$

The study participants were evaluated for the presence of pain, location of pain and intensity, Body Mass Index (BMI), daily activities, Geriatric Depression Scale (GDS) and Mini-Mental State Examination (MMSE), changes in gait, movement limitation, joint instability, joint stiffness, dizziness, number of falls and falls in the last 3 months. . $^{12,15,16}$

Several studies have analyzed the gait performance using walkways with electronic pressure sensors. Using the devices, were possible to calculate, among other variables, the waking speed, steps size, cadence (number of steps per minute) and the percentage of dual phase support. In addition, the carpet seems to have good sensitivity and specificity to assess risk of falls in the elderly. Among the most commonly used parameters in the literature are the speed, cadence, number of steps, stride length, gait variability step by step, symmetry left/right, percentage of gait cycle spent in progress, single or double support. ${ }^{17}$

For the gait assessment, initially we looked at whether the oldest old would be able to perform the activities proposed in the research, ability to walk without assistance of another person, without communication 
difficulties or imminent risk of falling. We used the Zeno Walkway ${ }^{\circledR}$, a rug with electronic pressure sensor produced by Protokinetics ${ }^{\circledR}$ with the dimensions $66 \mathrm{~cm} \times 4.62 \mathrm{~m}$. Protokinetics system ${ }^{\circledR}$ was validated in different environments to access spatiotemporal measures. ${ }^{18}$ Participants performed two set of tests: a usual pace walk than a fast pace walk over the rug. In order, to exclude the acceleration and deceleration gait phases, they started walking one meter before and stopped one meter after the rug. The Protokinetics system ${ }^{\circledR}$ software provides several gait parameters. We captured step length and time, stride length and time, walking speed and cadence in both paces. ${ }^{18}$

The contribution of acupuncture treatment in improving symptoms and gait was evidenced by a new assessment after 10 acupuncture sessions. An experienced and qualified professional performed the acupuncture sessions. This professional did not participate in the initial and final evaluation questionnaires, not compromising the fidelity of the results. The sessions had a frequency of twice a week and treatment was performed individually, for different protocols points according to the illness or pain reported by each patient. ${ }^{11}$ The acupuncture points used in participants with low back pain were: VG4, B23, B246, B62, B24. The following points were used: E35, E36, BP6, Ig4, Yintang. The participants with pain in the shoulders and wrist were the points: P1, P2, F3, ID3, CS6, C7, VB20.

The depth of the insertion of the acupuncture points used in this study varied according to the stimulation, the mandrel used for the insertion of the needle causes the needle to reach a depth of $0.5 \mathrm{~cm}$, being able to with the stimulation (hourly rotation and anti-hour) reach $1 \mathrm{~cm}$ deep. The needle used in the study was with the size of $20 \times 30 \mathrm{MM}$, Dong Bang DBC brand. The acupuncture sessions lasted around 30-40 min.

The professional responsible for the sessions during the study has clinical experience and performance of 6 years, having his training in acupuncture being done in a specialization course of 2.5 years.

All data were collected by using TeleForm ${ }^{\circledR}$ program, which creates scannable forms. Subsequently the data will be analyzed using Epi Info 7.0 program. The results of evaluations were compared between the two oldest-old groups before and after completion of all the acupuncture sessions. After the initial evaluation, the mean differences of continuous variables of different tests were tested by Student's t test. Cross-tabulations between categorical variables and the two groups will be tested by chi-square. A p $<0.05$ was considered statistically significant and between 0.1 and 0.05 as a significant trend.

\section{RESULTS}

We evaluated 23 oldest-old identified by AMPAL as candidates for acupuncture sessions. Of these, 7 oldest-old (30\%) were unable to finish the 10 sessions proposed and the final evaluation. Sixteen oldest-old completed the ten acupuncture sessions and evaluations proposed. Table 1 compares the demographic and clinical characteristics of the participants who finished or drop-off the proposed intervention. They did not differ significantly regarding the distribution by sex, mean age BMI and GDS, or level of self-perceived health average.

Table 1. Distribution of participants who completed the intervention and those who drop-off by demographic and clinical characteristics.

\begin{tabular}{lccc}
\hline & $\begin{array}{c}\text { Finish the } \\
\text { research }\end{array}$ & $\begin{array}{c}\text { Did not finish } \\
\text { research }\end{array}$ & p \\
Sex & $5(31.3 \%)$ & $2(28.6 \%)$ & 0.6494 \\
$\quad$ Male & $11(68.7 \%)$ & $5(71.4 \%)$ & \\
$\quad$ Female & $84.1 \pm 3.10$ & $83.0 \pm 1.83$ & 0.3841 \\
Age $( \pm$ SD years $)$ & $26.9 \pm 4.08$ & $27.8 \pm 3.81$ & 0.6533 \\
BMI $\left( \pm\right.$ SD Kg $\left./ \mathrm{m}^{2}\right)$ & $4.0 \pm 2.56$ & $4.3 \pm 2.34$ & 0.7957 \\
GDS $( \pm$ SD) & & & 0.3432 \\
Self-perceived health & $1(6.3 \%)$ & $2(28.6 \%)$ & \\
$\quad$ Excellent & $12(75.0 \%)$ & $4(57.1 \%)$ & \\
Good & $3(18.7 \%)$ & $1(14.3 \%)$ & \\
Regular & & & \\
\hline
\end{tabular}

* SD=standard deviation; BMI=body mass index; GDS=Geriatric Depression Scale

We observe in Table 2 that the most frequent pain was in the lumbar spine followed by knee pain. The average degree of pain intensity varied between 5.3 and 9 in different painful regions in the initial evaluation. In the final evaluation, pain intensity decreased in almost all places listed initially as shown in Figure 1. The only one oldest-old participant did not reported any change in pain. She had pain in the ankle and foot. The other painful places reduced between 24 and 100\%. In three places (thigh, popliteal region and abdomen), the pain reduced completely.

Table 3 shows the gait parameters, measured by Zeno walkway, initial and final evaluation as well as the average of the differences between the two evaluations. We observe an improvement in the length of step and stride, speed and cadence after the intervention in both gait paces. Time parameters remained similar in both step and stride movements. Average stride length $(\mathrm{p}=0.0459)$, speed $(\mathrm{p}=0.061)$ and cadence $(p=0.0194)$ in fast pace gait test e differences in speed $(p=0.0177)$ and cadence $(p=0.0078)$ between 
usual and fast paces, were significantly different before and after the intervention. Stride length in fast pace improved before and after the intervention reaching a significant trend $(\mathrm{p}=0.0892)$.

Table 2. Frequency and intensity of joint pain before and after acupuncture.

\begin{tabular}{lcccc}
\hline Local & \multicolumn{1}{c}{$\mathbf{n}$} & $\begin{array}{c}\text { First } \\
\text { Evaluation }\end{array}$ & $\begin{array}{c}\text { Last } \\
\text { Evaluation }\end{array}$ & $\mathbf{p}$ \\
Lumbar spine & $12(75 \%)$ & $6.7 \pm 1.70$ & $4.2 \pm 0.47$ & 0.01 \\
Knee & $10(63 \%)$ & $5.9 \pm 2.81$ & $4.5 \pm 2.84$ & 0.28 \\
Shoulder & $8(50 \%)$ & $6.8 \pm 2.12$ & $3.6 \pm 3.29$ & 0.04 \\
Wrist and hand & $7(44 \%)$ & $5.7 \pm 1.70$ & $2.1 \pm 2.34$ & 0.01 \\
Inguinal region/hip & $4(25 \%)$ & $6.0 \pm 1.15$ & $2.5 \pm 1.00$ & $<0.01$ \\
Calf & $3(19 \%)$ & $5.3 \pm 2.89$ & $3.7 \pm 2.31$ & 0.48 \\
Thigh & $2(13 \%)$ & $6.0 \pm 1.41$ & $0.0 \pm 0.00$ & 0.03 \\
Neck & $2(13 \%)$ & $7.5 \pm 2.12$ & $2.5 \pm 2.12$ & 0.14 \\
Head/face & $2(13 \%)$ & $8.0 \pm 1.41$ & $2.0 \pm 1.41$ & 0.05 \\
Popliteal region & $2(13 \%)$ & $5.0 \pm 0.00$ & $0.0 \pm 0.00$ & $<0.01$ \\
Abdomen top & $1(6 \%)$ & 6.0 & 0.0 & \\
Parietal region & $1(6 \%)$ & 9.0 & 1.0 & \\
Ankle and foot & $1(6 \%)$ & 7.0 & 7.0 & \\
\hline
\end{tabular}

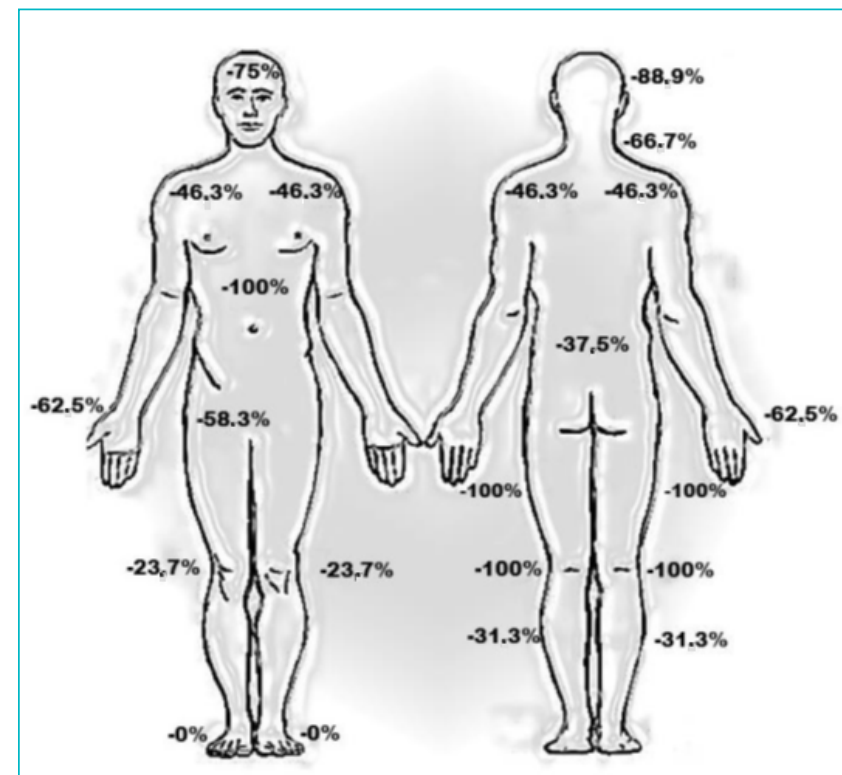

Figure 1. Pain reduction after Acupuncture treatment.

Table 3. Gait Assessment before and after acupuncture intervention.

\begin{tabular}{|c|c|c|c|c|c|c|c|}
\hline \multirow{2}{*}{ Test } & \multicolumn{2}{|c|}{ Before } & \multicolumn{2}{|c|}{ After } & \multicolumn{2}{|c|}{ Difference } & \multirow{2}{*}{$\mathbf{p}$} \\
\hline & mean & DP & mean & DP & mean & DP & \\
\hline \multicolumn{8}{|l|}{ Step evaluation } \\
\hline Length, usual pace & 49.2 & 7.20 & 50.8 & 7.76 & 1.54 & 7.032 & 0.1910 \\
\hline Length, fast pace & 55.2 & 7.33 & 58.2 & 11.03 & 2.99 & 7.106 & 0.0459 \\
\hline Difference in length & 6.0 & 2.65 & 7.5 & 6.17 & 1.46 & 6.329 & 0.1785 \\
\hline Time, usual pace & 0.6 & 0.11 & 0.6 & 0.08 & -0.02 & 0.101 & 0.7930 \\
\hline Time, fast pace & 0.5 & 0.07 & 0.5 & 0.07 & -0.03 & 0.065 & 0.9673 \\
\hline Difference in time & -0.1 & 0.05 & -0.1 & 0.05 & -0.01 & 0.061 & 0.7306 \\
\hline \multicolumn{8}{|l|}{ Stride evaluation } \\
\hline Length, usual pace & 99.5 & 13.81 & 103.5 & 16.60 & 4.01 & 15.080 & 0.1439 \\
\hline Length, fast pace & 111.2 & 15.39 & 115.9 & 22.05 & 4.68 & 13.918 & 0.0892 \\
\hline Difference in length & 11.8 & 5.44 & 12.4 & 14.65 & 0.67 & 14.901 & 0.4282 \\
\hline Time, usual pace & 1.3 & 0.25 & 1.2 & 0.17 & -0.04 & 0.190 & 0.7863 \\
\hline Time, fast pace & 1.1 & 0.15 & 1.0 & 0.13 & -0.07 & 0.159 & 0.9669 \\
\hline Difference in time & -0.2 & 0.12 & -0.2 & 0.11 & -0.04 & 0.108 & 0.9037 \\
\hline \multicolumn{8}{|l|}{ Speed } \\
\hline Usual pace & 82.4 & 21.52 & 87.1 & 21.16 & 4.64 & 19.962 & 0.1761 \\
\hline Fast pace & 106.0 & 22.62 & 118.8 & 29.95 & 12.83 & 20.504 & 0.0061 \\
\hline Difference & 23.6 & 6.57 & 31.8 & 14.89 & 8.19 & 15.578 & 0.0177 \\
\hline \multicolumn{8}{|l|}{ Cadence } \\
\hline Usual pace & 97.9 & 15.99 & 99.6 & 12.25 & 1.66 & 11.896 & 0.2878 \\
\hline Fast pace & 113.2 & 13.47 & 120.5 & 15.09 & 7.27 & 14.070 & 0.0194 \\
\hline Difference & 15.3 & 7.32 & 20.9 & 10.01 & 5.60 & 9.268 & 0.0078 \\
\hline
\end{tabular}




\section{DISCUSSION}

The results of this study demonstrate that acupuncture can be effective to improve the diverse types of pain in the oldest old. The literature does not have any data showing that acupuncture interventions improve the pain of the oldest old, but many studies already address the beneficial effects of this intervention on pain relief. This study showed an improvement in both pain subjectively, through subjective evaluation through the pain questionnaire. The evaluation of gait parameters was important in the objective evaluation of pain that demonstrated the improvement of parameters through an objective assessment. ${ }^{19-22}$

The spatial parameters (step length and last) and temporal (time step and last) to assess the performance of gait. ${ }^{23}$ The study data show a significant improvement in the pace of the steps in the implementation of rapid march, which corroborate the kinematic patterns of the significant increase in stride length and stride, decreased time between steps, although not significantly, and favoring speed throughout the cycle. With the increase of the cadence, there was a greater number of steps and pastes, which suggest a smaller variability and unsteadiness during the gait cycle. These data corroborate with another study that demonstrated good acupuncture outcomes in the walk of patients with osteoarthritis in the knee. ${ }^{24}$

Data from an animal model study demonstrated beneficial effects of electroacupuncture in rats with spinal cord injury in gait. After a few weeks of treatment, the mice showed a gradual increase in gait performance, with a significant improvement in the duration, the length and the speed of the walk..$^{25}$

The significant improvement in quality of the gait is related to the step length and the last time is controlled by muscular mechanisms, especially hip extensors and flexors knee. Maintaining the elasticity and neuro-motor control of these muscles favor the initial contact of the foot at the beginning of the step and the last. On the other hand weakness and muscular disability of lower limbs, generate functional adaptations throughout the process of movement, demanding greater neuromuscular control for your execution. ${ }^{26}$ The elderly tend to decrease the speed and stride length, increasing the support base and the time of the double support phase to gain stability and equilibrium. ${ }^{27}$ The investigated specific gait parameters in elderly patients to determine whether they persisted in high gear and idle. Among the changes emphasizes the reduction of arc hip movement, which can limit the step length and reduce the driving speed. In this context, acupuncture significantly reduced pain at the thigh in patients who participated in this research. These findings would support the improvement in the speed of rapid traverse and the comparative pre and post acupuncture in action to move from place..$^{28}$

Whereas changes in the gait of the elderly are due to the loss of functional reserve, the improvement of referred pain from the acupuncture intervention favored the kinematic parameters. The decrease in pain symptoms reduces energy expenditure spent during the gait cycle, favoring pelvic rotation and consequently increasing the walking speed and stride. Making maintains the increased gait variability in the elderly is due to pathological factors rather than factors from age and the length of the support base and the time of the double support phase are controlled by postural mechanisms, namely, an increase in values means a gain of stability. ${ }^{27}$

Acupuncture can also influence analgesia, relaxation and pain relief, promoting the well-being because it involves the stimulation of small diameter nerves which carry messages to the spinal cord, which activates neurons in the brain stem and hypothalamus firing mechanisms endogenous opioids. The answer is on the endorphins, encephalin and hormones related to improvement of stress, pain and inflammation. ${ }^{29-30}$

The present study has as its main limitation to involve few participants, mainly women and the absence of control group. However, this study has as its main robustness the use gait as an objective measure of pain improvement. As mentioned before, most former studies on pain intervention are based in subject parameters such as visual analogic scale. Participants of our study referred taking less analgesic medicines after the acupuncture intervention.

\section{CONCLUSION}

In conclusion with this study, that the treatment of acupuncture in oldest-old patients who have pain and consequently poor walking, can greatly improve these symptoms, acupuncture was effective in reducing chronic pain and improving longevity gait performance. It has contributed significantly to mobility and strength. The authors conclude that acupuncture can be an efficient complementary treatment of elderly people as an effective treatment option available in the Primary Care of the Brazilian Public Health Service.

\section{ACKNOWLEDGMENTS}

This work was supported by grants from CNPq and Capes. 


\section{REFERENCES}

1. Porciúncula RC da, Carvalho EF de, Barreto KML, Leite VMM. Perfil socioepidemiológico e autonomia de longevos em Recife-PE, Nordeste do Brasil. Rev Bras Geriatr Gerontol. 2014;17(2):315-25

2. Galvão O, Ferreira L, Maciel SC, Maria S, Costa G, Oliveira A, et al. Active Aging And Its Relationship To Functional Independence. Texto Context - enferm. 2012;21(3):513-8.

3. Kaeberlein M, Rabinovitch PS, Martin GM. Healthy aging: the ultimate preventative medicine. Science [Internet]. 2015 Dec. 4;350(6265):1191-3. Available from: http://www. ncbi.nlm.nih.gov/pmc/articles/PMC4793924/

4. Lima MG, Belon AP, Barros MBA. Happy life expectancy among older adults: differences by sex and functional limitations. Rev Saude Publica [Internet]. Faculdade de Saúde Pública da Universidade de São Paulo; 2016 Oct. 26;50:64. Available from: http://www.ncbi.nlm.nih.gov/pmc/ articles/PMC5117521/

5. Ribeiro A. Características funcionais da Fragilidade em longevos. Dissertação (Mestrado). Porto Alegre: PUCRS; 2013.

6. Semba RD, Varadhan R, Bartali B, Ferrucci L, Ricks MO, Blaum C, et al. Low serum carotenoids and development of severe walking disability among older women living in the community: The Women's Health and Aging Study I. Age Ageing. 2007;36(1):62-7.

7. Nunes DP, Duarte YA de O, Santos JLF, Lebrão ML. Screening for frailty in older adults using a self-reported instrument. Rev Saude Publica [Internet]. Faculdade de Saúde Pública da Universidade de São Paulo. 2015 Feb. 19;49:2. Available from: http://www.ncbi.nlm.nih.gov/pmc/ articles/PMC4386551/

8. Pegorari MS, Tavares DM dos S. Factors associated with the frailty syndrome in elderly individuals living in the urban area . Rev Lat Am Enfermagem [Internet]. Escola de Enfermagem de Ribeirão Preto/Universidade de São Paulo; 2014 May 20;22(5):874-82. Available from: http://www. ncbi.nlm.nih.gov/pmc/articles/PMC4292678/

9. Santos F, Gouveia G, Martelli P, Vasconcelos E. Acupuntura no Sistema Único de Saúde e a inserção de profissionais não-médicos. Rev Bras Fisioter. 2009;13(4):330-4.

10. Sousa IMC De, Bodstein RCDA, Tesser CD, Santos FDADS, Hortale VA. Práticas integrativas e complementares: oferta e produção de atendimentos no SUS e em municípios selecionados. Cad Saude Publica [Internet]. 2012;28(11):2143-54. Available from: http://www.scielosp. org/scielo.php?script =sci_arttext\&amp $\% 5$ Cnpid $=$ S0102 311 X2012001100014

11. Zuppa C, Prado CH d., Wieck A, Zaparte A, Barbosa A, Bauer ME. Acupuncture for sleep quality, BDNF levels and immunosenescence: A randomized controlled study. Neurosci Lett [Internet]. Elsevier Ireland Ltd; 2015;587: 35-40. Available from: http://linkinghub.elsevier.com/ retrieve/pii/S0304394014009525

12. Xue Q-L, Bandeen-Roche K, Varadhan R, Zhou J, Fried LP. Initial manifestations of frailty criteria and the development of frailty phenotype in the Women's Health and Aging Study II. J Gerontol A Biol Sci Med Sci. 2008;63(9):984-90.

13. Brasil. Ministério da Saúde. Departamento de Atenção Básica. Envelhecimento e Saúde da pessoa idosa. Vol. 19: Caderno de Atenção Básica; 2006. 192 p.
14. Barbosa, Bruno Rossi; Almeida, Joyce Marques de; Barbosa, Mirna Rossi; Rossi-Barbosa LAR. Avaliação da capacidade funcional dos idosos e fatores associados à incapacidade. Cien Saude Colet. 2014;29(8):3317-25.

15. Santiago LM, Mattos IE. Depressive symptoms in institutionalized older adults. Rev Saude Publica [Internet]. Faculdade de Saúde Pública da Universidade de São Paulo. 2014 Apr. 27;48(2):216-24. Available from: http://www. ncbi.nlm.nih.gov/pmc/articles/PMC4206148/

16. Silva L dos SV e, Oliveira GM de, Yokomizo JE, Saran LF, Bottino CM de C, Yassuda MS. The Geriatric Anxiety Inventory in primary care: applicability and psychometric characteristics of the original and short form. Arch Clin Psychiatry (São Paulo) [Internet]. 2016;43(5):103-6. Available from: http://www.scielo.br/scielo.php?script $=$ sci arttext\&pid $=$ S0101-60832016000500103\&lng=en\&nrm = iso\&tlng $=\mathrm{en}$

17. Lynall RC, Zukowski LA, Plummer P, Mihalik JP. Reliability and validity of the protokinetics movement analysis software in measuring center of pressure during walking. Gait Posture [Internet]. 2017 Feb.;52:308-11. Available from: http://www. sciencedirect.com/science/article/pii/S0966636216307111

18. Kraan CM, Tan AHJ, Cornish KM. The developmental dynamics of gait maturation with a focus on spatiotemporal measures. Gait Posture [Internet]. Elsevier; 2018 Mar. 27;51:208-17. Available from: http://dx.doi.org/10.1016/ j.gaitpost.2016.10.021

19. Schröder S, Meyer-Hamme G, Friedemann T, Kirch S, Hauck M, Plaetke R, et al. Immediate Pain Relief in Adhesive Capsulitis by Acupuncture - A Randomized Controlled Double-Blinded Study. Pain Med [Internet]. 2017;1-13. Available from: https:/academic.oup.com/painmedicine/ articlelookup/doi/10.1093/pm/pnx052

20. Guerra De Hoyos JA, Mart??n MDCA, Leon EBYB De, Lopez MV, Lopez TM, Morilla FAV, et al. Randomised trial of long term effect of acupuncture for shoulder pain. Pain. 2004;112(3):289-98.

21. He D, Høstmark AT, Veiersted KB, Medbø JI. Effect of intensive acupuncture on pain-related social and psychological variables for women with chronic neck and shoulder pain - an RCT with six month and three year follow up. 2005;23(2):52-61.

22. Couilliot M-F, Darees V, Delahaye G, Ercolano P, Carcaillé M, Vytopilova P, et al. Acceptability of an Acupuncture Intervention for Geriatric Chronic Pain: An Open Pilot Study. J Integr Med [Internet]. 2013;11(1):26-31. Available from: http://www.ncbi.nlm.nih.gov/pubmed/23464643

23. Sterke CS, van Beeck EF, Looman CWN, Kressig RW, van der Cammen TJM. An electronic walkway can predict short-term fall risk in nursing home residents with dementia. Gait Posture [Internet]. Elsevier B.V. 2012;36(1): 95-101. Available from: http://dx.doi.org/10.1016/j. gaitpost.2012.01.012

24. Liu Y-H, Wei I-P, Wang T-M, Lu T-W, Lin J-G. Immediate Effects of Acupuncture Treatment on Intra- and Inter-Limb Contributions to Body Support During Gait in Patients with Bilateral Medial Knee Osteoarthritis. Am J Chin Med [Internet]. World Scientific Publishing Co.; 2017 Jan. 1;45(1):23-35. Available from: http://dx.doi.org/10.1142/ S0192415X17500033

25. Escobar-Corona C, Torres-Castillo S, Rodríguez-Torres EE, Segura-Alegría B, Jiménez-Estrada I, Quiroz-González S. 
Electroacupuncture improves gait locomotion, H-reflex and ventral root potentials of spinal compression injured rats. Brain Res Bull [Internet]. 2017 May;131:7-17. Available from: http://www.sciencedirect.com/science/article/pii/ S0361923016304348

26. Abreu SS, Caldas CP. Velocidade de marcha, equilíbrio e idade: um estudo correlacional entre idosas praticantes e idosas não praticantes de um programa de exercícios terapêuticos. Rev Bras Fisioter. 2008;12(4): 324-30.

27. Maki BE. Gait changes in older adults: predictors of falls or indicators of fear. J Am Geriatr Soc. 1997;45(3): 313-20.
28. Kerrigan DC, Todd MK, Della Croce U, Lipsitz L a., Collins JJ. Biomechanical gait alterations independent of speed in the healthy elderly: Evidence for specific limiting impairments. Arch Phys Med Rehabil. 1998;79:317-22.

29. Ma S-X. Neurobiology of Acupuncture: Toward CAM. Evid Based Complement Alternat Med [Internet]. 2004 June 1;1(1):41-7. Available from: http://www.pubmedcentral. nih.gov/articlerender.fcgi artid $=442119 \&$ tool $=$ pmcentrez \&rendertype $=$ abstract

30. Medeiros R De, Saad M. Acupuntura: efeitos fisiológicos além do efeito placebo. O Mundo da Saúde [Internet]. 2009;33(1):69-72 [cited 2014 February 18]. Available from: http://www.saocamilo-sp.br/pdf/mundo_saude/66/69a72.p 